\title{
The Comparative Dialectics of Islam, Politics, and Government in Indonesia and Thailand
}

\author{
${ }^{1 *}$ Ahmad Anfasul Marom; ${ }^{2 *}$ Bayu Mitra Adhyatma Kusuma \\ ${ }^{1,2}$ Institute of Southeast Asian Islam, Sunan Kalijaga State Islamic University, Yogyakarta, Indonesia
}

\begin{abstract}
The religion particularly Islam has a considerable influence on the politics and governmental system in a country generally. But of course, the role of Islam in politics and government will be different when Islam as the majority religion compared when Islam became a minority religion. It becomes interesting to be explored further, so as to see concrete evidence the authors determined to compare the dialectic of Islam in the politics and government in Indonesia and Thailand. The results of research showed that there is a significant imbalance between the role of Islam in Indonesia and Thailand for politics and government. In Indonesia since the struggle until independence era, the Muslim leaders and activists are aware that in order to improve the condition of the country, it takes a political struggle to deal with attempts to obtain power to influence government and public policy making. This can be evidenced by the existence of Islamic party or Islamic mass-based party from the first general election to date. In addition, at the level of government the role of Muslim activists and scholars are also greatly affected. Instead, in Thailand show that Islam has a small portion in politics and government. This is evidenced by the lack of political access and opportunity to participate in the governmental system. Even in a particular regime, Muslims get very discriminatory treatment. Like as in the administration of Prime Minister Phibul Songkhram and Thaksin Shinawatra. This condition is supported by the prevailing political system in Thailand, where the authority of the regime is absolute and inviolable. As an impact, insurgents' groups in Southern Thailand namely National Revolution Row (BRN) and Pattani United Liberation Organization (PULO) continued to express special autonomy. With the special autonomy it is expected that the conflict in Southern Thailand will subside.
\end{abstract}

Keywords: comparative dialectic, Islam, politics, government

\section{Research Background}

Humans have a nature to always achieve the various desires and goals. One aim is to achieve power, either individually or in groups. Power is the ability of a person or group of people to influence a person's or other groups behavior such a way that it becomes a behavior in accordance with the wishes and goals of the people who have the power (Budiarjo, 2007). It can be said

\footnotetext{
* Corresponding author: Ahmad Anfasul Marom anfasul@gmail.com

Published online at http://islamicinsights.ub.ac.id/2018- 1

Copyright (C) 2018 PSP2M UB Publishing. All Rights Reserved
}

that achieve the power is a normal phenomenon in any individual or group. In the context of state, the efforts to achieve power are usually reached through political channels where one goal is to dominate the governmental system. Ibn Khaldun in Muqaddimah argued that politics is one special feature which is unique to human. Therefore, in politics, human should indicate the best aspects in him. The best aspects of life can be constructed from religion and morality (Affandi, 2004). 
Stating that Islam is only related to the spiritual life, without anything to do at all with the community and the state, may be as remote from reality by stating that Islam has provided a system of social, economic and political which thorough and detailed (Osman, 1983). The relationship between religion particularly Islam with the politics and government has a very long history. In the journey of that history, religion experiencing contacts with the sociocultural realities and engage directly or indirectly in the level of politics and government, moreover Islam has an important role in growing the sociopolitical attitude and behavior. Broader understanding towards politics and government will make its correlation with Islam become clearer.

The term of politics in the Islamic figh according Imam Hanbali is about attitude, behavior and public policy which is juxtapose toward people benefits (Amin, 2009). Muhammad SAW, beside as the last prophet and messenger, he is also the leader of the Islamic government in Medina that until today his saying still neatly written about politics, government, public administration and state constitutional law (Syafi'ie, 2006). Although it is undeniable that in this world too many secular states that considers religion has nothing to do with the state. So that they do not includes religion as a government affair. But in fact, many countries have shown that religion has a close link with politics and government. For example, are politics and government relations with Islam in Indonesia, with Buddhists in Thailand, with Hindu in India, or with Christian and Catholic in European countries. So, it can be said that religion has become an integral part of the history of politics and government in many countries.
Despite the fact that the relationship between Islam with the politics and government has a very long history, regrettable that the theoretical discourse about it has just evolved throughout the past four decades alone (Effendy, 2009). It has indicated some people think that the treasures of the development of Islam with the politics and government only occur significantly in the Middle East region. As we know that currently, moderate Islamist has attempted to integrate them into the political system of the Middle East (DeGregorio, 2010). So that most people in the west automatically identify Islam with Arabs, the reality Arabs only make up around $15 \%$ of the world's Muslim (Choi, 1996). Meanwhile, in the other parts of the world is less from attention and consideration. Whereas the spread of Muslims not only in the Middle East region, but also in various corners of the world, including in the Southeast Asian region. The spread of Islam in Southeast Asia do not only occur in countries whose majority are Muslims like Indonesia, Malaysia and Brunei Darussalam. But also in countries whose majority are the other religions, such as Thailand that politics and government are run by Buddhist principles.

Indonesia is a country with the largest Muslim population in the world, although in Indonesian Islam is not the official state religion (Suaedy, 2010). It's different with Malaysia who has formally declared Islam as the official state religion. In Indonesia, Islamic symbol and Islamic concept are prominent in political affairs (Ricklefs, 2012). It is given that the majority of Indonesia's population is Muslim, so mastering and controlling their sound and support is very important in maintaining political and governmental stability. In Indonesia, identity politics are loaded by religious 
issue, beside ethnicity and political ideology (Maarif, 2010). While, in Thailand Muslims are minority where they mostly live in southern Thailand. Generally, as minority groups, Muslims in Thailand are difficult to access their political rights, especially to involve in the governmental system.

Muslim has much experience both as minorities or majorities within a region. They were initially minorities in Mecca and later when Muslim bijrah to Abyssinia and Medina (Siddiqi, 2006). The process of the dialectic between Islam with politics and government in predominantly Muslim countries such as Indonesia is different in countries where Muslims are a minority like in Thailand. Therefore, it becomes interesting to find points of difference and similarity. Important to review the deeper how does the existence of Islamic political parties or Islamic mass-based political party in Indonesia and its influence on the governmental system. Besides that, this paper will analyze and examine about the relation between the Government of Thailand towards South Thai minority Muslim group in the context of politics.

\section{Dialectic Process between Islam and Politics in Indonesia and Thailand}

Islam is an important factor that must be considered if we want to understand about the politics and government in Indonesia. Indonesia's Islamic intellectuals and activist participate in a lively publishing scene. One of the recurring themes is the relationship between Islam, modernity and the nation state (Barton, 2011). One characteristic of Islamic tradition in Indonesia is the belief that Islam is a way of life that is comprehensive and integrated. Religion has an integral and organic relationship with politics and government. Since the beginning, the Indonesian leaders and Muslim activists are aware that improvement is concerned it requires a political struggle, which is dealing with efforts to gain power. As an ability to influence the actions and thoughts of others and influence public policy-making process, power through political way is very important.

In the colonial era, Islamic leaders and organizations have emerged as a symbol of political resistance against the Dutch colonial. These organizations are such as Sarekat Islam, Muhammadiyah and Nahdlatul Ulama. As the Islamic reform began to be introduced to the Netherland Indie, the most important of which was the rise Muslim leaders, the reformist, who had the same voices as those presented by the new priyayi graduated from Dutch schools. And the reformist course was then followed, albeit still distinctive, by the santri community under the leadership of the ulama of pesantren (Burhanudin, 2014).

For the next evidence can be seen from the history of the Indonesian struggle in the early days of independence was encouraging Islamic leaders to implement policies that confrontational, in the application area can appear in a variety of faces, such as the fight for the loading of Islamic law in the constitution through the Jakarta Charter and mastery in legislators, namely the House of Representatives, to the physical struggle, it can be seen from the opposition Islamic groups in the name of Islam as a symbol of the struggle against the government. And also to confirm the identity that distinguishes itself with other groups, to control of the government bureaucracy.

After the end of the New Order regime, political Islam emerged as a great 
power that controls the formal political structure. Cornelis Lay mentions that in contrast to the position of Islam in the new order that is attenuated by the stigma of fundamentalist or extremist. In reformation order, the activity of political Islam can move more freely. Some activists who must live as a political prisoner in the new order was released and returned to have political rights. Most of them then entered and form parties with Islam as the jib ideology, generate a huge wave of political shift, from an underground guerrilla politics, into formal politics at the surface. More than that, the emergence of political Islam is a collective political cooperation between political forces of Islam that so long assumed to be difficult to meet between Islamic modernists and Islamic traditionalist (Lay, 2006).

From the aspect of political party, the Islamic based party and the Islamic mass-based party (Pseudo-Islamic party) have existed since the first Indonesia's general elections held in in 1955. From time to time religious-based parties continue to emerge. Since Shura Council of the Indonesian Muslim Party (Masyumi), Nahdlatul Ulama Party (NU), United Development Party (PPP), National Awakening Party (PKB), National Mandate Party (PAN), until Prosperous Justice Party (PKS). At least there are four main reasons. First, theologically there is a claim that religion is an integral and holistic entity that governs every dimension. Second, historically there is an opinion that ulama have a big share in forming, maintaining the existence and sovereignty of Indonesia. Third, the religious label is deemed to have a sale value in the presence of voters and has a market share of permanent voters. Finally, the secular parties are deemed not capable of being articulator good for the interests of the ulama (Pamungkas, 2012). But unfortunately, the emergence of the new Islamic parties actually is from the cleavage of an Islamic party into several blocks. For the example, the emergence of Reformation Star Party (PBR) due to a split in the PPP and Ulama's National Awakening Party (PKNU) which is an offshoot of PKB. Figures that are not satisfied form their own new block (Syafiie \& Azhari, 2008).

In the history of general elections in Indonesia, the sound of Islamic parties and Islamic mass-based party reached the top of his voice gains in 1955 general elections which is about $48 \%$. But in the subsequent eras, the voice of Islamic parties and Islamic mass-based party continued to decline precipitously. Even in the 1999 election, the votes of Islamicbased party only $18 \%$ of the overall vote. This happens because several things, among others are: First, a mistake in reading the sociological reality of the ummah. Islam abangan has less interested towards religion labeled party, whereas they are the majority of voters. Second, the movement in the religious community as results of socio-economic transformation. So that's why the Islamic ummah in general only accept Islam as a religion, not as a political party. Third, the political accommodation of political party which outside the Islamic party against the interests of the ulama. Fourth, by the Islamic party politicians, Islam just for politicization and used as a political commodity without a sincere intention to fight for Islam. Fifth, influential Muslims leaders prefer to build their own party. Lastly, more Islamic party appeared exclusivity perceived threats from other segments of the electorate (Antlov \& Cederroth, 2004). In the past, Islamic parties are often considered to represent the Muslims so that the aspirations of the people are often identified with the 
aspirations of the party, even though they are not. Because only some Muslims who entered the party with Islamic principles (Harun, 1986).

Based on the paragraph above can be said that the Islamic party does not necessarily carry the mission of Islam. But Zachary Abuza mentions that after discussing the performance of Islamic parties in past election, political Islam appears to be growing popularity and influences (Abuza, 2007). Similar with Abuza, Robert W. Hefner has referred to the purification of society (Hefner, 2000). But somehow Islamic parties and Islamic mass-based parties continue to enliven the general election in Indonesia until nowadays. Thus it can be said that Islam always color and play a major role in the history of politics in Indonesia.

While in Thailand, the dialectic of Islam with politics is certainly different in Indonesia. As we know that Islam is not the majority religion in Thailand because most Thais are Buddhist, both of Mabayan and Hinayan. Islam arrived in Thailand is estimated to around the $10^{\text {th }}$ century brought by Arab and Indian traders. Islam once ruled Pattani region since the founding of the Islamic Kingdom of Pattani in $14^{\text {th }}$ century. However, since being a part of the Kingdom of Siam, until now Muslims are a minority and discriminated against by the government of Thailand. Thai Muslims largely spread across three southern provinces, namely Pattani, Yala, and Narathiwat. And added by two surrounding area, namely Songkhla and Satun.

At the first, the Muslims in Thailand were not given political access. Muslims are not allowed to have Islambased political parties and even the organization must be based nationalist.
The government has formed a kind of ranks mufti named Culamantri, usually lifted it a pious who can lick and can play back the verse until he later issued a fatwa that against towards the Buddhist powers is haram. At certain moments exhibited all heavy weapons, military equipment. Then they invited Muslim scholars to look, with the hope of growing fear of revolt. However, they still struggle to establish a sovereign state with Islamic principles, namely the Islamic Republic of Pattani (Sholeh, 2007).

The fall of the military regime in 1973, and the enforcement of democracy, which lasted until 1976 when General Kriangsak Chomanan take over the civilian government represents a new era in the world of Thai politics. Every layer of society are encouraged to participate in the affairs of all evils including social, political and economic have been covered under the dictatorship regime lifted to the surface. Similarly with the range of emotions that had been found among the Malay-Muslim during this time. Various groups have sprung up in response to the democratic atmosphere and strive for coordinated the affairs of their community. To fight for their rights, Thai Muslims ever plan to establish Islamic-based party in 2007. According to sources who involved in the process of formation of the party, the party name is Ruam Thai Muslim (United Muslim of Thailand). But until now the party has not declared yet (Kaseng, 2013).

The optimism of the founders of the party that they will have the support of Muslims, especially in the southern region of Thailand that is predominantly Muslim, is still to be tested. Because the number of Thai Muslims even expressed concern the existence of this party will exacerbate the dilemma they have 
experienced over the years. Some people even argue that Thai Muslim should join political parties that already exist. In this way is expected to help the Muslims to fight for their rights through their representatives. From that phenomenon, we can conclude that there is a difference of opinion among Thai Muslims themselves in terms of politics. Thus, we can conclude also that in terms of politics, Muslims in Indonesia is far more advanced than Muslims in Thailand.

\section{Islamic Role in the} Governmental System as a Result of the Dialectic between Islam and Politics in Indonesia

One reason why academics believe that political parties are essential to governing is the rather 'perverse and unorthodox' belief that 'voters are not fools' (White, 2006). Dialectic of Islam and politics are so closely geared to the government are very thick with the nuances of Islam. Quite often Muslim leaders or scholars become a presidential or vice president candidate alongside a nationalist political actor. As happened in 2004 elections in which Salahuddin Wahid advanced accompany Wiranto, Hasyim Muzadi accompanied Megawati Soekarnoputri and also Amien Rais who ran for president in pairs with Siswono Yudhohusodo. Wiranto-Wahid carried by coalition of Work Group Party (Golkar) and PKB. While SoekarnoputriMuzadi nominated by the Indonesian Democratic Party of Struggle (PDI-P). And the candidate of Rais-Yudhohusodo carried by PAN and PKS (Pamungkas S. , 2009).

In the end it is only a few who can reach the top, but at least the dialectic of Islam and politics are able to deliver Islamic leaders and scholars occupy a very strategic position in the government, such as Abdurrrahman Wahid who became president and Amien Rais who became the chairman of the People's Consultative Assembly (MPR). From these phenomena we need to remember is how PAN played a key role in moving the large coalition called the poros tengah which later won the competition to deliver Abdurrahman Wahid became fourth president of the Republic of Indonesia. The success of Abdurrahman Wahid became president also must be supported by other Islamic mass-based parties such as the PKB. In fact to be honest, the victory of Joko Widodo-Jusuf Kalla in the 2014 presidential elections also causes the support of Kyai and Islamic mass-based party.

After the monetary and political crisis in 1997 and 1998, Indonesia entering a transition phase from autocratic to democratic government which called reformasi. This transition accompanied by decentralization process which resulted local autonomy and democracy, beside make the governmental system in Indonesia became more transparent. In the local level, governments in Indonesia are not only led by male Muslim, but also female Muslim. Their appearance as the winner in the local general elections is because they are capable of cooperating with Islamic organizations and leaders. An example is Rustriningsih in Kebumen Regency, Ratna Ani Lestari in Banyuwangi Regency and Siti Qomariah in Pekalongan. The success of the three women in their positions as the number one people in the regency or city level cannot be separated from the role and support of Kyai, particularly of Nahdlatul Ulama as the dominant religious orientation. 
Not only were the three of them able to win the local general election because the support of Islamic parties and ulama. In other areas, there Ratu Atut Chosiyah who became the governor of Banten Province through the support from the coalition of $\mathrm{PKB}, \mathrm{PAN}$, PKNU, and The Star and Crescent Party (PBB), and other eight nationalist parties. The family member of Chosiyah namely Airin Rachmy Diani in South Tangerang also became a mayor supported by PKS. In South Tangerang, PKS was successful in downplaying its Islamist message and focusing on an anti-corruption platform to influence the secular-minded voters. And the last evidence in this paper is Haryanti Sutrisno in Kediri Regency who supported by the coalition of PPP, PKNU and some nationalist party. Overall, in term of religion, all the female leaders elected in Java have been Muslim. Thus it can be concluded that the combination of female politicians and Islamic background is very attractive to people who have the right to vote in the local general election. In addition, clientelism is also a major factor for the rise of Muslim women in political contestation in Indonesia. An example is a Fatayat bond. Fatayat bond is strong enough to use as a clientelistic networks that greatly contributed to the capital vote (Triantini, 2015).

The emergence of Indonesian Muslim women in local politics did not just suddenly occur. While the postSuharto transformation of the vision and mission of official state women's organization played an important role in facilitating the awakening of Indonesian women's role in politics and government, a more significant catalyst was the rise of progressive Islam, which sought to promote greater participation of women in politics including in position as the leadership (Dewi, 2015). In the reform era, politics is more open. The issue of representation of women has become a hot commodity. The emergence of female Muslim leaders in the local level is the manifestations of the political openness. Besides the rising of Muslim leaders in the national and local level, a further indicator of rising Islamism is the increase in the number of local laws which attempt to enforce tenets of Sharia at a provincial or sub-provincial level (Hasan, 2009).

The role of religion especially Islam, in the Indonesian political sphere is still very large. This is because Indonesian people are predominantly Muslim, so the issue of Islam is considered as the most effective $\mathrm{m}$ edia in influencing the psychology of the masses and gain support for a particular political party. Although it must be admitted that these conditions are also influenced by the religious views of the conservative side. Religious conservatism is now mainstream politics in Indonesia and many individuals or groups with antipluralist agendas are now entrenched in the state apparatus (Bush, 2015). Moreover, the strong assumption that power is sacred because God granted to certain people, to represent the power of God in the world (Asy'arie, 2005). It is about the same as in Thailand, but the difference is in Thailand that politics and government are run with the principles of Buddhism.

\section{Contemporary Relation between Islam and Government in Thailand}

In the grassroots level of society, in fact discrimination against Muslims is not great or visible. Even people enough respect to the existence of Muslims relatively. The problem is precisely discrimination by the authority conductor or the government (Navi, 
2015). The lack of political access for Muslims in Thailand resulted in the absence of the Islamic influence in governmental system. Even put a Muslim in the level of government is a very difficult thing. Until nowadays, Muslim in southern Thailand, Muslims is only given a position as a Soso or representatives of local communities whose position is still under the governor (Hanif, 2015). Early relations between the Kingdom of Thailand and the Islamic government in the south are based on the framework of the river system and the country's weak government recognizes the supremacy of the king of Thailand. In practice, they regularly sent tribute in the form of silver and gold. This means that historically a vassal state like Pattani have some autonomy in self-government while maintaining the status of streams with Siam (Aphornsuvan, 2003).

Since 1906, in accordance with the decision of the United Kingdom, the Kingdom of Siam formally took over the northern Malay region, which consists of Pattani, Narathiwat, Songkhla, Satun and Yala, which later became part of the province of the Kingdom of Thailand. Meanwhile in other news that is had to the north, Kelantan, Perlis and Terengganu, may be included as part of the Kingdom of Malaysia by the United Kingdom. Cultural clash between Malay Muslims and Thai Buddhist are unavoidable. At the beginning of the Thai government controlled by military General Pibul Songkhram who led the 1938-1944 and 1947-1957, the policy of Thai cultural nationalism became the primary policy. Starting from the efforts to strongly use the Thai language and culture in all of part of Thailand, including the South region, pose a very strong resistance for the Malay Muslims in southern Thailand who speak Malay. The integration of government policies and programs are very concerned about the people of Thailand Muslims in southern Thailand.

In 1940 certain cultural rules such as wearing Western-style clothing, adopt Thai names if you want to enter government schools or if you want to apply for jobs in the government ranks came into effect and enforced. Malay danger is strictly prohibited taught in public schools or used in conversations with government officials. The Songkhram's policy above is supported by the prevailing political system in Thailand, where the ruling authority is absolute and inviolable. Rulers tend to use a variety of methods to ensure compliance with minority and controlling any countervailing power. Such systems are applicable in the governmental system of Thailand, known as "bureaucratic politics" which means strong government control over people's lives. But this is precisely the policy imposed to reinforce the identity of Thai Muslims in south to oppose. That policy has provoked uprisings and separatist movements in southern Thailand, the movements of which; National Revolution Row (BRN) and Pattani United Liberation Organization (PULO).

Besides General Phibul Songkhram, Thailand leader who also publish controversial policies against Muslims in the south are Prime Ministers Thaksin Shinawatra. Shinawatra's controversial policies are policies against the separatists in Pattani, Yala and Narathiwat provinces in southern Thailand. In an effort to resolve the conflict, the King of Thailand called on the government to approach on their welfare. But instead Shinawatra actually imposed martial law since January 5, 2004. Interestingly according to 
Shinawatra, known as the Thais are: they are Buddhist or speak Thai. If a person is a Muslim, then they should speak Thai, or they could not speak the Thai language as long as they embraced Buddhism. Of course, this policy raises many problems especially among Thai Muslims. Shinawatra's Opinion is developing prejudice and negative stigma to Muslim Malays as criminal groups who hide behind religion. That stigma is utilized Thai troops to deploy military operations in the southern region. Shinawatra's statement is certainly ignited a larger conflict.

Although in terms of politics they are part of the Thai nation, but honestly they are part of the Malay race who use Malay language and culture and is geographically located adjacent to the Kingdom of Malaysia, which is also the majority of the nation's population is Malay. Suppose could choose, they apparently would prefer one with Malaysia, or split off into its own country. Therefore, integration and assimilation policy of the government getting tough response from the Muslim minority and has given rise to armed conflict between minority groups and governments (Dahamae, 2015). For the Thai government, religious differences are still a taboo. In Thailand generally, religious feast became a national holiday celebration only Buddhism. Eid celebration is only assigned as a holiday in southern Thailand (Humanica, 2015).

In addition, they are isolated from the State and the government, not only because the central government is far from that area, and alienation from the state, but more due to the differences in religion, language and culture. So that assimilation and integration which the government is expected to be difficult to achieve. In contrast, Thailand impressed
Muslims tend to isolate themselves, it is because having trouble adapting. First, because most of them (especially those living in rural areas such as Pattani, Yala, and Narathiwat) can only speak Thai a little or not at all. This makes them unable to communicate with Thai people mostly.

The isolated feeling and dissatisfaction increasingly intense when the Pattani nobility unplug from all power and all positions which they held before being transferred to bureaucrats from Bangkok or from the Northern provinces, which have a language, religion and culture are different from the Muslim community. Therefore, the problem for the Thai minority Muslim since the first are how they should participate in the political process in their country which is based on Buddhist cosmology, representing the State bureaucracy is dominated by the ThaiBuddhist. Various state ceremonies and rituals are all Buddhist in terms of form and content, and the most important is that the bureaucracy has the power to change the values and institutions of social and cultural, including religious values to suit the needs of the State.

Although the Thai government had been taboo to admit southern region as an area which has special autonomy, is now beginning to change. The Government is aware that the means of coercion, discrimination and oppression far proved fruitless that is beneficial to both parties. Yingluck Shinawatra became prime minister since August 2011 taking a more moderate political policy to face the rebels than the previous administration. Preliminary talks about a peace deal through dialogue among South Thai Muslim and the Government of Thailand has been agreed and signed in Kuala Lumpur Malaysia on February 
28,2013 . This agreement is involving the Government of Thailand and the South Thai Muslim. The deal for the preliminary talks for peace through negotiations agreed by both parties witnessed by Malaysian Prime Minister Najib Razak and Thai Prime Minister at that time Yingluck Shinawatra. Preliminary agreement document of peace talks will be the basis for what is called a process of dialogue for peace in the provinces of Southern Thailand. A preliminary agreement to discuss peace in Southern Thailand is a historic step, especially for Muslim. To bring peace and create a good relationship between the government and Islam in South Thailand, Thailand also learns from Indonesia. Thailand's king sent a special delegation that is named King Prajadhipok's Institute of Thailand to seek input on how to resolve the conflict in Aceh, which was considered quite successful (Octastefani, 2015).

This step should be followed up as was the case in the Southern Philippines. Philippine President Benigno Aquino submits proposed legislation to the parliament for give autonomy to the Muslim minority as an important step in efforts to end the rebellion. Submission to congress is seen as significant because it means Aquino and Moro Islamic Liberation Front (MILF) have reached an agreement related to the legal basis of government authority in the south of the country's Muslim. The implementation of special autonomy seems to be a wise choice in the dialectic of Islam with politics and government in Thailand, particularly the southern region. With special autonomy, the Thai government still has control of the southern region. On the other hand, the Muslim people in the South Thai can maintain their tradition. Thai Muslim in south can also have an official political channel and the government is a representation of Thai Muslim. Thus, the special autonomy is a win-win solution which confers a benefit on both sides of the dispute in the dialectic between Islam, politics and government in Southern Thailand.

\section{Concluding Remarks}

Humans have a natural instinct for gain the power. In order to achieve the power, people generally use political path, which ultimately wants to be the ruler in the governmental system. To remember that, according Ibn Khaldun people must prioritize the aspects of religion and morality in the politics. Islam does not only relate to the spiritual life, but also the various social aspects of society. Dialectic between Islam and politics has a long history. Although most countries in the world is very secular and denying religion in government affairs, but in fact many countries showing that religion gives a great influence on politics and government. Indonesia is a country with the largest Muslim population in the world. Although basically Indonesia is never declaring Islam as the official state religion. In Indonesia, the concepts and symbols of Islam are very influential in the politics and government. This is in contrast with the conditions in Thailand, where Muslims are a minority who are often discriminated in the terms of politics and government.

In Indonesia, Muslim activists and leaders have a major role in the struggle period for independence in colonial times to the Old Order regime. In the New Order regime, Islam sidelined from the politics and government with the stigma that Islam is a representation of fundamentalists and extremists. After the New Order regime has collapse, Islam became a major political force. Most of them form a party with Islam as its 
ideological foundation. In the context of political parties, Islam has coloring the history of politics and government in Indonesia. Since the first general election in 1955 until 2014, the Islamic based party and Islamic mass-based party (Pseudo-Islamic party) can reap significant noise. Although basically Islamic party does not necessarily carry the mission of Islam in their existence. In the context of the government, Islam is able to deliver their prominent figures to occupy strategic positions in the governmental system of Indonesia, such as Abdurrahman Wahid as the president and Amien Rais as the chairman of MPR. Moreover, at the local level are emerging leaders who are supported by the Islamic party, organization, or figures. Those local leaders are not only male Muslim but also female Muslim.

In Thailand, the condition is opposites with the condition in Indonesia. In the context of politic, Islam does not have a big role. Muslims in Thailand are often discriminated and not given to political access. Islamic parties are forbidden to stand up, because the whole mass organizations are only allowed to use as a nationalist ideology. The absence of political access has an impact on the absence of Islamic role in the government of Thailand. In the governmental system, Muslim only has given the position as a Soso who represent local communities in Southern Thailand. Ironically the position of Soso in the government level is still below the governor who appointed by Bangkok. Then the Thai government appointed a mufti who made a fatwa that against the Buddhist government in Thailand is haram. During the administration of General Phibul Songkhram and Prime Minister Thaksin Shinawatra, Muslims are forced to adopt Thai culture and Buddhist religion. Resulting in the emergence of the Muslim resistance to the government of Thailand which represented by insurgents' groups such as the BRN and PULO. Until nowadays, Muslims in southern Thailand continued to seek the enactment of special autonomy. In the past, special autonomy is taboo for the government of Thailand, but in Yingluck Shinawatra regime the government begins to soften. The implementation of special autonomy in Southern Thailand seems to be a wise choice in the bridging for the dialectic of Islam with politics and government.

\section{Bibliography}

Abuza, Z. (2007). Political Islam and Violence in Indonesia. London: Routledge.

Affandi, H. I. (2004). The Roots of Conflict in All Period: Elaboration of Ibn Khaldun's Thought. Yogyakarta:: Pustaka Pelajar.

Amin, S. M. (2009). Ilmu Dakwah [The Science of Dakwah]. Jakarta: Amzah.

Antlov, H., \& Cederroth, S. (2004). Election in Indonesia: The New Order and Beyond. London: Routledge.

Aphornsuvan, T. (2003). History and Politics of the Muslim in Thailand. Bangkok: Thammasat University.

Asy'arie, M. (2005). NKRI, Budaya Politik. dan Pendidikan. Yogyakarta: Lesfi.

Barton, G. (2011). Islamic Indonesia: A Seculer Democracy? Dalam S. A. Prasetyo, Pluralisme, Dialog dan 
Keadilan (hal. 85). Yogyakarta: Interfidei.

Budiarjo, M. (2007). Dasar-Dasar Ilmu Politik [The Principle of Political Science]. Jakarta: Gramedia Pustaka Utama.

Burhanudin, J. (2014). The Dutch Colonial Policy on Islam: Reading the Intellectual Journey of Snouck Hurgronje. Al-Jami'ah: Journal of Islamic Studies Vol. 52, No. 1,, 53.

Bush, R. (2015). Religious Politics and Minority Right during the Yudhoyono Presidency. Dalam E. A. al., The Yudhoyono Presidency: Indonesia's Decade of Stability and Stagnation (hal. 255). Singapore: Institute of Southeast Asian Studies Press.

Choi, D. (1996). The Process of Islamization and its Impact on Indonesia. Comparative Civilization Review No. 34, 11-26.

Dahamae, A. (2015, November 16). (A. A. Marom, Pewawancara)

DeGregorio, C. (2010). Islamism in Politics: Integration and Persecution in Egypt. Al-Jamiah: Journal of Islamic Studies Vol. 48, No. 2.

Dewi, K. H. (2015). Indonesian Women and Local Politics: Islam, Gender and Networks in Post-Subarto Indonesia. Singapore: National University of Singapore Press.
Effendy, B. (2009). Islam dan Negara: Transformasi Gagasan dan Praktik Politik Islam di Indonesia . Jakarta: Paramadina.

Hanif, M. (2015, October 7). (B. M. Kusuma, Pewawancara)

Harun, L. (1986, October 22). Mulai Ditinggalkan, Aspirasi Umat Islam Lewat Kelembagaan Formal. Kompas.

Hasan, N. (2009). The Making of Public Islam: Piety, Agency and Commodification on the Landscape of the Indonesian Public Sphere. Contemporary Islam Vol. 3, No. 3, 230.

Hefner, R. W. (2000). Civil Islam: Muslims and Democratization in Indonesia. Princeton: Princeton University Press.

Humanica, D. S. (2015, October 6). (A. A. Marom, Pewawancara)

Kaseng, M. (2013, November 16). (A. A. Marom, Pewawancara)

Lay, C. (2006). Involusi Politik: Esei-Esei Transisi Indonesia. Yogyakarta: PLOD and JIP UGM.

Maarif, A. (2010). Politik Identitas dan Masa Depan Pluralisme Kita. Jakarta: Paramadina.

Navi, I. (2015, November 30). (B. M. Kusuma, Pewawancara)

Octastefani, T. (2015, November 6). (A. A. Marom, Pewawancara) 
Osman, F. (1983). Parameters of the Islamic State. Arabia: The Islamic World Review (17), 10.

Pamungkas, S. (2009). Perihal Pemilu. Yogyakarta: JIP UGM Laboratory.

Pamungkas, S. (2012). Partai Politik: Teori dan Praktik di Indonesia.

Yogyakarta: Institute for Democracy and Welfarism.

Ricklefs, M. (2012). Islamisation and Its

Opponents in Java: A Political, Social, Cultural and Religious History (1930 to the Present). Singapore: National University of Singapore Press.

Sholeh, B. (2007). Muslim Minority, Conflict and Reconciliation in Southern Thailand. The Journal of International Relations Vol. 2, No. 1.

Siddiqi, M. Y. (2006). The Prophet

Muhammad SAW: A Role Model for

Muslim Minorities. Leicestershire: :

The Islamic Foundation.

Suaedy, A. (2010). Islam and Minorities: Managing Identity in Malaysia. Al-Jami'ab: Journal of Islamic Studies Vol. 48, No. 1, , 3 .

Syafi'ie, I. (2006). Ilmu Administrasi Publike [Public Administrative Science]. Jakarta: Rineka Cipta.

Syafiie, I., \& Azhari. (2008). Sistem Politile Indonesia . Bandung: Refika Aditama.

Triantini, Z. E. (2015). Blora, Jawa Tengah: Sabet Sebagai Penentu
Kemenangan. Dalam E. Aspinall, \& M. Sukmajati, Politik Uang di Indonesia: Patronase dan Klientelisme pada Pemilu Legislatif 2014. Yogyakarta: PolGov.

White, J. K. (2006). What is a Political Party? Dalam R. S. Katz, \& W. Crotty, Handbook of Party Politics (hal. 9). London: Sage Publications. 